Europe's Journal of Psychology, 7(1), pp. 17-39

www.ejop.org

\title{
Job demands, job control, social support and self-efficacy beliefs as determinants of burnout among physical education teachers
}

\author{
André Brouwers \\ Welko Tomic \\ Huibrecht Boluijt \\ The Open University, Heerlen, The Netherlands
}

\begin{abstract}
The aim of the present study, which involved 311 Physical Education (PE) teachers in Dutch schools, was to examine the relationships between job demands, job control, social support and perceived self-efficacy on the one hand and teacher burnout on the other. Based on Karasek's Demands-Control-Support model (1990), it was expected that perceived stringent job demands in combination with perceived lack of control on the job and perceived lack of social support from colleagues, principals and managers could so affect teachers' health that they were likely to suffer from enhanced levels of burnout. Our study partly confirmed results based on the Karasek model. It was also expected that the number of domain-determined self-efficacy beliefs concerning the influence teachers had on job demands would affect their level of burnout. However, this supposition was not supported. Perceived job control was found to have a moderating effect on the relationship between perceived job demands on the one hand and the emotional exhaustion and depersonalization dimensions of burnout on the other. Colleague support had a moderating effect on the relationship between job demands and the personal accomplishment dimension of burnout, whereas managerial support had a moderating effect on self-efficacy beliefs concerning teachers' influence on job demands and personal accomplishment. The study further revealed that PE teachers run a greater risk of falling victim to burnout as they grow older. Implications for future studies are discussed.
\end{abstract}

Keywords: burnout, P.E. teachers, self-efficacy, job demands-control-support model. 
Burnout has been identified as one particular type of chronic response to the cumulative, long-term negative impact of work stresses (Blase, 1982). In a general sense there is agreement that burnout is a multi-dimensional construct. These dimensions are inter-related, but at the same time they are independent entities. Maslach and Jackson (1986) state that burnout is a syndrome of emotional exhaustion, depersonalization, and a reduced sense of personal accomplishment which can occur among individuals who work with people in some capacity. Individuals who are burned out appear to lack emotional resources and suffer a high degree of depersonalization. They are unable to list more than a scant few personal accomplishments.

One specific category of human service professionals who appear to be vulnerable to burnout are teachers. In 1998, 38\% of the 4800 employees who were declared unfit for work in the Netherlands were teachers (Magnée, 2000). Figures published by the Dutch Industrial Insurance Administration Office show that psychological complaints together with complaints concerning the loco-motor apparatus are the main causes for full or partial disablement (Smulders, 1995). These findings are in line with research showing that a significant number of teachers consider leaving their job and feel fed up with their work (Berkhout, Zijl \& Van Praag, 1998; Friedman \& Farber, 1992). American and British studies reveal that many teachers quit their jobs (Farber, 1991; Merseth, 1992), or, if they do not, experience much stress (Borg, 1990). However, there has been little research into burnout among secondary school teachers who teach the same subject (homogeneous groups of teachers). Indeed, the opposite is true: teacher burnout is examined among heterogeneous groups of teachers, irrespective of the subject they teach.

An exception to this rule is the study carried out by Hodge, Jupp and Taylor (1994) on burnout among music and mathematics teachers. Another example is a study on physical strain among physical education (P. E.) teachers (De Vries, Beune, Simons and Thijsen, 2000). Unfortunately, it is doubtful whether the method they used in their study can reveal the exact determinants of burnout among teachers of specific school subjects. When attempting to explain burnout, it is plausible that workload and amount of control are variables that differ considerably from one group of subject teachers to the next. The activities students are engaged in during their lessons, the way they interact, the way the teacher supervises and coaches the students, the time the teacher spends on preparing lessons and marking papers, and the way the classroom is organized all differ considerably from subject to subject. In order to be able to express sound opinions on a specific category of teachers, we think burnout studies involving teachers in general should be complemented by studies involving teachers who all teach the same subject. In addition, we also 
intend to compare the various groups of subject teachers with one another with respect to burnout.

The current study was conducted among Physical Education (PE) teachers. Burnout is a phenomenon of dramatic importance in education in general, and PE teachers are also at risk for burnout prematurely. Rakovac and Heimer (2008) studied 479 PE teachers and found that $62.8 \%$ reported health disturbances. Some complaints were related to mental health factors. PE teachers without health impairments reported being satisfied with their work conditions, interpersonal relationships, students' behavior, relationships with supervisors and rewards (Rakovac \& Heimer, 2008).

PE teachers have received little attention in the burnout literature. After consulting databanks such as PsycINFO, ERIC, and Current Contents, we found just a few studies examining determinants of burnout among PE teachers systematically. Psychological, social and bureaucratic factors correlated significantly with burnout (Smith \& Leng, 2003). Exactly the same association with burnout was reported with regard to the average class size of special education students (Fejgin, Talmor, \& Erlich, 2005), and job satisfaction (Koustelios \& Tsigilis, 2005). With regard to Job Demand Control model factors, Lee (2004) found that role ambiguity, work overload and role conflict were positively associated with one burnout dimension, i.e. emotional exhaustion, whereas peer support was positively associated with the personal accomplishment dimension. Unlike Lee (2004), Fejgin, Talmor, and Erlich (2005) found that PE teachers' personal resources and workload did not significantly correlate with burnout (Fejgin, Ephraty, \& Ben-Sira, 1995).

Looking at the present knowledge of determinants of burnout among PE teachers and some conflicting results regarding this issue, it is very important to further investigate how PE teachers experience their work. In comparison with teachers of other subjects, some striking differences are the skills that students have to be taught and the way lessons are organized. In PE lessons, for example, students are trained to optimize their physical ability, to cooperate with others when performing physical activities, and to control their emotions in competition situations. A PE teacher has to cope with students who may be boisterous, noisy, and intractable. The teacher's voice is a very important instrument. Sometimes he or she has to be lenient and approachable and at other times very strict, e.g. to avoid risk and undesirable physical contact. At the end of the day, the teacher may be physically and mentally exhausted. PE teachers teach their lessons in a gym or on the sports field. Although they do not have to mark papers, they do have to mark the students' achievements. The main problem is the PE teacher's position on the school team: PE 
lessons do not contribute to the students' academic achievements, which are considered to be of primary importance for their future careers. PE teachers may become frustrated by having their lessons systematically undervalued by colleagues, principals, and parents.

Social support, workload, and control

A number of studies have found that perceived lack of social support from colleagues, i.e. a lack of friendship and assistance, may be an important element in teacher burnout (Brownell \& Pajares, 1997; Burke, Greenglass, \& Schwarzer, 1996; Burke, Shearer, \& Deszca, 1984; Dignam \& West, 1988; Punch \& Tuettemann, 1990; Ross, Altmaier, \& Russell, 1989; Schwab, Jackson, \& Schuler, 1984). Social support from colleagues and principals helps prevent emotional exhaustion, depersonalization and a perceived lack of personal accomplishment. A statement like "some stressors from the workplace may never be overcome by individual efforts..." shows the importance of social support in this respect (Glass \& McKnight, 1996). The level of support can be assessed by measuring the discrepancy between a person's need for emotional support and the amount and intensity of the supportive interactions that someone actually experiences (Van Sonderen, 1991). Studies on the subject show that a perceived lack of social support is more important than support that is actually received, in that its negative effects override the positive ones (Bacharach, Bainberger, \& Mitchell, 1990; Brissie, Hoover-Dempsey, \& Bassler, 1988; Burke \& Greenglass, 1989a, 1993; Burke et al., 1996; Jackson et al., 1986; Kuzsman \& Schnall, 1987; Russell et al., 1987; Travers \& Cooper, 1993; Zabel \& Zabel, 1982).

In the present study we examined workload, level of job control, and social support as determinants of burnout among PE teachers. These variables, which are presented in the Karasek (1990) model, turned out to be important explanatory factors for the degree of burnout. Studies on this subject showed that the more serious the degree of burnout was among teachers, the more taxing their tasks were (job demands), the less job control they experienced, and the less support they seemed to get from colleagues and principals. Concurring with Karasek's model, these studies also revealed that job demands showed a stronger correlation with burnout when job control was reduced. Therefore, it was hypothesized that job control as well as support from colleagues and school leaders moderate the relationship between job demand and burnout. 
Self-efficacy

Bandura (1997, p. 3) defines self-efficacy as "...the beliefs in one's capabilities to organize and execute the courses of action required to produce given attainments". The courses of action over which a person can exercise control are manifold; they may be concerned not only with actions, but with motivation, thought, and emotions as well. The consequences are also numerous and involve someone's ability to cope with misfortunes or to become aware of thought patterns that obstruct or stimulate intended actions. Self-efficacy is also related to stress (Bandura, 1997; Vrugt, 1997) and the feelings of depression (Kanfer \& Zeiss, 1983; Kavanagh, 1992) that someone experiences when dealing with taxing environmental demands. Self-efficacy beliefs are domain and task specific (Bandura, 1997; Tschannen-Moran \& Woolfolk Hoy, 2002; Woodruff \& Cashman, 1993).

The present study also examined the relationship between self-efficacy and burnout. The variable "self-efficacy beliefs" can be viewed as an important addition to the Karasek model in studies on burnout. Whereas job demands, job control, and social support are job-related characteristics as perceived by the respondent himself, selfefficacy beliefs may reveal how effectively a teacher copes with these job characteristics. As job demands in particular play an important role in explaining teacher burnout, the self-efficacy beliefs in our study have been specified according to the job demands domain, i.e., self-efficacy beliefs influencing the teacher's perceived job demands. This specification led us to our first assumption: self-efficacy beliefs in the job-demands domain will explain part of the variance in burnout among teachers that is not explained by the job demands-control-support variables. Our second assumption was that the specified self-efficacy beliefs about influencing job demands will show stronger associations with burnout the more support teachers get from the school management. Therefore, it was hypothesized that self-efficacy beliefs in the job-demands domain moderates the relationship between job demand and burnout.

PE teachers who feel they have the support of the school management will be more inclined to try to improve their work situation by raising objections to job demands they dislike. However, it is to be expected that only those teachers who strongly believe that they are able to influence their job demands will approach the school management on this subject. Teachers who doubt their capabilities in this respect will probably not find it easy to take their troubles to the school management, even though the school management would provide them with support. Therefore, it was 
hypothesized that school management support moderates the relationship between self-efficacy beliefs in the job-demands domain and burnout.

Method

Participants

The participants of the present study were PE teachers employed in general secondary education in the Netherlands. The total number of PE teachers was 4594, $3262(71 \%)$ of them male and 1332 (29\%) of them female (Centrale Financiën Instellingen, 2007). By kind permission of The Association of Physical Education Teachers, we obtained a random sample of 500 PE teachers who were employed in general secondary schools.

In order to match the male/female distribution in the population, for a random sample of 500 PE teachers approximately 355 males and 145 females are required. Therefore, to prepare a list of 500 teachers, every ninth male and female teacher was selected. All teachers were eligible for the study. In order to try and raise the response rate, we followed suggestions made by Green and Hutchinson (1996): we provided respondents with postage-paid envelopes, sent the questionnaires directly to the respondents, told the respondents to contact us at any time if necessary, and kept the questionnaire fairly short. As we approached 500 teachers and had 311 responses, the response rate was 62\%, which Babbie (1995) finds adequate for surveys and which is also in accordance with the findings of Asch, Jedrziewski, and Christakis (1997).

A total of 311 completed questionnaires were returned. The sample consisted of 94 female (30.2\%) and 217 male teachers (69.8\%). The average age of the teachers was 41.19 years (SD $=11.05)$, ranging from 21 to 63 years old. The mean number of years that the subjects had taught gym was 18.85 (SD =11.29), ranging from 1 to 39 . The mean number of weekly hours spent teaching gym was 20.26 (SD = 7.05). There was no significant difference between the 311 respondents and the total population of PE teachers on the variable age: $t(469)=1.33, p=>.05$. The same result applied to gender: $x^{2}(1)=.04, p=>.05$.

In order to try and raise the response rate, we followed suggestions made by Green and Hutchinson (1996): we provided respondents with postage-paid envelopes, sent the questionnaires directly to the respondents, told the respondents to contact us at any time if necessary, and kept the questionnaire fairly short. 
As we approached 500 teachers and had 311 responses, the response rate was $62 \%$, which Babbie (1995) finds adequate for surveys and which is also in accordance with the findings of Asch, Jedrziewski, and Christakis (1997).

Measures

Burnout. The Dutch version of the Maslach Burnout Inventory for teachers (MBI-NL-Ed; Schaufeli \& Van Horn, 1995) was used to assess the PE teachers' burnout level. The instrument consists of twenty items, and is divided into three sub-scales: (1) emotional exhaustion (EE; 8 items), (2) depersonalization (DP; 5 items) and (3) personal accomplishment (PA; 7 items). Teachers could assign a score ranging from "never" to "always" on a 7-point scale. It is assumed that teachers suffer from burnout when their scores on emotional exhaustion and depersonalization are high, and their scores on personal accomplishment are low. Examples of items indicating emotional exhaustion are: "At the end of the working day I feel empty" and "I feel tired when I get up in the morning, facing a new working day again". The maximum score is 48. Examples of depersonalization items are: "I have the feeling that I treat some students in an impersonal way" and "I don't really care what will become of my students". The maximum score is 30. Examples of items indicating personal accomplishment: are "When I have finished my instruction, I look back on it full of satisfaction" and "I have the feeling I achieve many things of great value in this job". The maximum score is 42 . The three-factor structure of the Dutch version of the Maslach Burnout Inventory for teachers was investigated with confirmatory factor analysis (Schaufeli, Daamen, \& Van Mierlo, 1994).

Job demands. Job demands were measured on six items derived from a Dutch questionnaire on organizational stress (Vragenlijst Organisatiestress-Doetinchem, VOS-D; Bergers, Marcelissen \& De Wolff, 1986). The items were adapted to the teaching profession. Teachers could assign a score ranging from "seldom" to "very often" on a 5-point Likert scale. Examples of items are: "I have times when I (1) think that the total amount of work is too great, (2) feel that I have to work extra hard, and (3) feel I have onerous responsibilities in addition to teaching". The maximum score is 30. In a study on organizational characteristics, work characteristics, and relationships with psychological work reactions in a Dutch nursing sample, Tummers, et al. (2006) found a Cronbach's Alpha of .83 ( $N=379)$.

Control. Control was measured on six items derived from the Maastricht Autonomy Questionnaire (MAQ); De Jonge, Landeweerd \& Van Breukelen, 1994), an instrument for measuring autonomy or control in work situations. The items were adapted to the 
teaching profession. Our respondents could assign a score ranging from "very little" to "very much" on a 5-point Likert scale. Examples of items are: "I think that my job gives me the opportunity (1) to determine my working objectives myself, (2) to determine the teaching activities myself, (3) to personally determine which activities I will perform". The maximum score is 30. In a Dutch study on the relationships between job characteristics and psychological well-being, De Jonge, et al. (2001) used this scale and found a Cronbach's Alpha of .81 ( $N=261)$.

Colleague and School Management Support. Colleague and school management support were measured using items taken from the Emotional Support Subscale of the Social Support List - Discrepancies (SSL-D; Van Sonderen, 1991). We used six items to measure colleague support and the same six items for school management support. These items measure the extent to which teachers feel a discrepancy between their need for supportive interactions with colleagues and school managers on the one hand and the amount and intensity of supportive interaction actually offered to them on the other. The items were measured on a 4-point scale with a response format ranging from 1 to 4: "This never happens; This doesn't happen often enough; This happens fairly often; This happens too much." Since none of the participants in the present study chose the category "This happens fairly often; This happens too much" on any item of this scale, it was not necessary to test curvilinear relationships with other measured variables. The maximum score is 24 . In a Dutch study of the relationship between social support and well-being, Van Sonderen and Ormel (1997) used this scale and found a Cronbach's Alpha of .90 ( $N=304)$.

Self-Efficacy related to Influencing Job Demands. We measured self-efficacy beliefs related to teachers' influence on job demands with an instrument developed especially for this study, consisting of six items. The same formulations for measuring job demands were used, with teachers being asked to rate the extent to which they feel able to influence particular demands. The items were scored on a 6-point scale running from "totally disagree" to "completely agree". High scores on the items are indicative of strong self-efficacy beliefs. Examples of items are: "I am able to influence my work in such a way that I can (1) decrease the expected work pace, (2) reduce the instances when I have to work extra hard, (3) avoid having to take on too many responsibilities besides teaching". The maximum score is 30 .

\section{Procedure}

The questionnaires were mailed to the home addresses of randomly selected PE teachers. In the accompanying letter, we explained the purpose of the study and asked the teachers to participate by filling out the self-report questionnaires and 
sending them back anonymously and individually in postage-paid envelopes. To ensure a high response rate, the teachers were sent a written reminder asking them to return the completed forms anonymously in the postage-paid envelopes. We also used telephone reminders, since according to Asch et al. (1997), telephone reminders are associated with higher response rates.

\section{Results}

In order to be able to determine whether the five variables predicting burnout -i.e. job demands, job control, colleague support, school management support, and selfefficacy beliefs about influencing job demands- reflect five factors, we conducted a confirmatory factor analysis using the AMOS 6.1 computer program. A five-factor model was formulated in which the items that were supposed to measure the same variable (i.e., job demands) were loaded on one factor. To decide whether the fivefactor model fit the data, the Comparative Fit Index (CFI) was used, as research findings show that it is relatively independent of the sample size taken at random (Bentler, 1990). When the value of CFI turned out to be higher than Bentler and Bonett's (1980) recommended criterion of .90 , we assumed that the model could not be significantly improved. The results of the confirmatory factor analysis showed that the five-factor model fit the data quite well (null model: $\chi^{2}(435)=4404.40$; five-factor model: $\left.\chi^{2}(395)=713.35, \mathrm{CFI}=.92\right)$.

Table 1 shows the standardized regression coefficients of the five-factor model that can be interpreted as factor loadings. The lowest value of the standardized regression coefficients was .43 , which implies that the items loaded well on the factors in question.

After scaling, the means, standard deviations, and intercorrelations were computed (see Table 2). Reliability analysis resulted in Cronbach's Alphas of .91 for emotional exhaustion, .74 for depersonalization, .83 for personal accomplishment, .80 for job demands, .81 for control, .88 for colleague support, .92 for school management support, and .79 for self-efficacy beliefs about influencing job demands. The results of the reliability analysis show that only Cronbach's Alpha of the depersonalization subscale does not meet Nunnally and Bernstein's (1994) criterion of .80 (1978); the other scales are quite reliable. 
Table 1. Results of Confirmatory Factor Analysis of the Items of the Independent Variables.

Item No. Item

Factors

12

\section{Job Demands}

I have times when I

7. think the total amount of work is too great.

1. find the expected work pace too fast.

2. feel I have to work extra hard.

3. have to work on various tasks simultaneously.

14. feel I have onerous responsibilities in addition to teaching.

4. would like more moments when I could take it easy.

$\begin{array}{lllll}.80 & -- & -- & -- & -- \\ .72 & -- & -- & -- & -- \\ .69 & -- & -- & -- & -- \\ .62 & -- & -- & -- & -- \\ .58 & -- & -- & -- & -- \\ .47 & -- & -- & -- & --\end{array}$

\section{Autonomy / Control}

I think that my job gives me the opportunity to

3. determine my working objectives myself.

11. determine teaching activities myself.

4. determine the sequence of duties myself.

10. personally determine which activities I will perform.

1. choose my own way of working.

5. assess the quality of the results myself.

\section{Colleague Support}

This never happens; This doesn't happen often enough;

This happens fairly often:

This happens too much; my colleagues

5. encourage me.

3. give me a push in the right direction.

1. support me.

2. revive me or cheer me up.

6. help me clarify my problems.

4. give me good advice.

$\begin{array}{lllll}-- & .78 & -- & -- & -- \\ -- & .70 & -- & -- & -- \\ -- & .69 & -- & -- & -- \\ -- & .62 & -- & -- & -- \\ -- & .67 & -- & -- & -- \\ -- & .43 & -- & -- & --\end{array}$

\section{School Management Support}

This never happens; This doesn't happen often enough;

This happens fairly often;

This happens too much; the school management 
11. encourages me.

9. gives me a push in the right direction

10. gives me good advice.

8. revives me or cheers me up.

7. supports me.

12. helps me clarify my problems.

\section{Self-Efficacy Beliefs about Influencing Job demands}

I am able to influence my work in such a way that I can

1. reduce the expected work pace.

2. reduce the instances when I have to work extra hard.

4. build in moments during which I can take it easy.

7. avoid having too much work to do.

14. avoid taking on too many responsibilities besides teaching.

3. avoid being compelled to work on various tasks simultaneously.

$\begin{array}{lllll}-- & -- & -- & .85 & -- \\ -- & -- & -- & .85 & -- \\ -- & -- & -- & .83 & -- \\ -- & -- & -- & .80 & -- \\ -- & -- & -- & .77 & -- \\ -- & -- & -- & .77 & --\end{array}$

$\begin{array}{lllll}-- & -- & -- & -- & .71 \\ -- & -- & -- & -- & .69 \\ -- & -- & -- & -- & .63 \\ -- & -- & -- & -- & .61 \\ -- & -- & -- & -- & .53 \\ -- & -- & -- & -- & .53\end{array}$

Table 2. Means and Standard Deviations of the Variables and Correlations Between the Variables.

\begin{tabular}{|c|c|c|c|c|c|c|c|c|c|c|c|c|}
\hline Variable & $\mathrm{M}$ & SD & 1 & 2 & 3 & 4 & 5 & 6 & 7 & 8 & 9 & 10 \\
\hline 1. Sex & -- & -- & -- & & & & & & & & & \\
\hline 2. Age & 43.18 & 11.05 & $-.27 * \star$ & -- & & & & & & & & \\
\hline 3. Years of Teaching Gym & 20.26 & 7.05 & $-.21 * \star$ & $-.13 *$ & -- & & & & & & & \\
\hline 4. Job Demands & 2.84 & .74 & .03 & $.20 * \star$ & -.09 & -- & & & & & & \\
\hline 5. Control & 3.46 & .67 & .00 & $-.14 \star$ & $.11 *$ & $-.25 * *$ & -- & & & & & \\
\hline 6. Colleague Support & 2.57 & .50 & -.09 & -.02 & -.01 & $-.19 \star \star$ & .05 & -- & & & & \\
\hline 7. School Management Support & 2.16 & .52 & -.08 & -.05 & -.02 & $-.25 * \star$ & .08 & $.42 \star \star$ & -- & & & \\
\hline $\begin{array}{l}\text { 8. Self-Efficacy about Influencing } \\
\text { Job demands }\end{array}$ & 2.78 & .64 & $-.14 *$ & -.06 & .06 & $-.48 * *$ & $.42 * \star$ & $.18 * *$ & $.23 * \star$ & -- & & \\
\hline 9. Emotional Exhaustion & 16.96 & 9.22 & .08 & $.24 * \star$ & -.07 & $.64 * \star$ & $-.31 * *$ & $-.37 \star \star$ & $-.32 * \star$ & $-.42 * \star$ & -- & \\
\hline 10. Depersonalization & 6.25 & 4.14 & -.07 & $.15 \star \star$ & .02 & $.36 * *$ & $-.16 * \star$ & $-.35 * \star$ & $-.21 * \star$ & $-.22 * \star$ & $.58 * \star$ & -- \\
\hline 11. Personal Accomplishment & 27.96 & 5.80 & -.06 & $-.15 * \star$ & .05 & $-.14 *$ & $.25 * \star$ & $.17 \star \star$ & .11 & $.22 * \star$ & $-.39 * *$ & $-.49 * *$ \\
\hline
\end{tabular}

Personal Accomplishment

Note: $*<.05 ; * \star<.01$ 
The correlation analyses (see Table 2) showed that the older PE teachers are, the higher they score on job demands $(r=.20, p<.01)$ and the lower on job control; $r=$ $.14, p<.05)$. The stronger the self-efficacy beliefs reported by the PE teachers about influencing job demands, (1) the lower the extent of perceived job demands $(r=-$ $.48, p<.01)$, (2) the more opportunities they felt they had to control their work $(r=$ $.42, p<.01)$, and (3) the more support they got from their colleagues and school managers $(r=.18, p<.01 ; r=.23, p<.01$, respectively). The more job demands PE teachers experienced, the more likely they were to report (1) having fewer opportunities to control their work $(r=-.25, p<.01)$, and (2) having less support from their colleagues as well as from their school managers $(r=-.19, p<.01 ; r=-.25, p<$ .01 , respectively).

Hierarchical regression analyses were carried out in order to investigate to what extent job demands, job control, colleague and managerial support and selfefficacy beliefs, as well as the product variables job demands $x$ control, job demands $x$ colleague support, job demands $x$ school management support, job demands $x$ self-efficacy beliefs, and self-efficacy beliefs $x$ school management support, would explain their burnout level. In order to obtain beta-coefficients that were comparable with each other, we centered the variables job demands, job control, colleague and managerial support, and self-efficacy beliefs prior to the regression analyses. Furthermore, the variables gender, age, and the number of years of teaching experience were statistically controlled for. With each burnout dimension as a dependent variable, these control variables were added to the regression equation in step 1, followed by job demands, job control, colleague and managerial support and self-efficacy beliefs in step 2 and the product variables in step 3. 
Table 3. Results of Hierarchical Regression Analysis for the Predicting Variables of Emotional Exhaustion, Depersonalization and Personal Accomplishment.

\begin{tabular}{|c|c|c|c|c|c|c|c|c|c|}
\hline \multirow[b]{2}{*}{ Predicting Variable } & \multicolumn{3}{|c|}{ Emotional Exhaustion } & \multicolumn{3}{|c|}{$\begin{array}{l}\text { Depersonalization } \\
--------~\end{array}$} & \multicolumn{3}{|c|}{ Personal Accomplishment } \\
\hline & B & Beta & $\triangle \mathrm{R} 2$ & B & Beta & $\triangle \mathrm{R} 2$ & $\mathrm{~B}$ & Beta & $\triangle \mathrm{R} 2$ \\
\hline Step 1 & & & $.08 * *$ & & & .03 & & & $.04 *$ \\
\hline Sex & .20 & $.08 *$ & & -.15 & -.08 & & -.14 & -.08 & \\
\hline Age & .00 & $.12 \star *$ & & .00 & .04 & & -.01 & $-.14 *$ & \\
\hline Years of Teaching Gymnastics & .00 & .00 & & .00 & .03 & & .00 & .00 & \\
\hline Step 2 & & & $.44 * \star$ & & & $.21 * \star$ & & & $.08 * \star$ \\
\hline Job Demands & .77 & $.49 \star \star$ & & .30 & $.27 \star \star$ & & .00 & .02 & \\
\hline Control & -.23 & $-.13 * \star$ & & .00 & -.05 & & .21 & $.17 \star \star$ & \\
\hline Colleague Support & -.45 & $-.20 * *$ & & -.43 & $-.26 * \star$ & & .18 & .11 & \\
\hline School Management Support & -.15 & -.08 & & .00 & -.03 & & .00 & .03 & \\
\hline Self-Efficacy about Influencing Workload & .00 & -.04 & & .00 & .01 & & .14 & .11 & \\
\hline Step 3 & & & .02 & & & $.04 *$ & & & .03 \\
\hline Job demands $\times$ Control & -.22 & $-.10 *$ & & -.24 & $-.16 * \star$ & & .00 & -.03 & \\
\hline Job demands x Colleague Support & -.14 & -.05 & & -.21 & -.10 & & .30 & $.14 *$ & \\
\hline $\begin{array}{l}\text { Job demands } x \text { School Management Support } \\
\text { Job demands } \times \text { Self-Efficacy Influence }\end{array}$ & .00 & -.01 & & .00 & .05 & & -.11 & -.07 & \\
\hline $\begin{array}{l}\text { Job demands } \\
\text { Self-Efficacy Influence Job demands } x\end{array}$ & .00 & -.02 & & .00 & -.04 & & .11 & .07 & \\
\hline School Management Support & -.18 & -.07 & & -.11 & -.06 & & .29 & $.16 *$ & \\
\hline F-Total for the Equation & & 25.37 & & & 8.15 & & & 3.90 & ** \\
\hline
\end{tabular}

Note. $* \mathrm{p}<.05 ; * * \mathrm{p}<.01$ 
Emotional exhaustion

The results of the hierarchical regression analyses (Table 3) revealed that both age and gender showed a significant and positive correlation with the burnout dimension emotional exhaustion $(\beta=.12, p<.01)$. Of the variables added in step 2 , only job demands $(\beta=.49, \mathrm{p}<.01)$, job control $(\beta=-.13, \mathrm{p}<.01)$ and colleague support $(\beta=-.20, p<.01)$ were significantly related to emotional exhaustion. Of all the product variables that were incorporated in step 3 of the regression equation, only job demands $x$ job control appeared to be significantly related to emotional exhaustion $(\beta=-.10, p<.05)$. This means that the correlation between job demands and emotional exhaustion was lower the more teachers felt they could determine the way they worked (job control).

\section{Depersonalization}

The variance in the depersonalization dimension of burnout was only significantly explained by job demands $(\beta=.27, \mathrm{p}<.01)$, colleague support $(\beta=-.26, \mathrm{p}<.01)$ and the product variable job demands $x$ control $(\beta=-.16, p<.01)$. High levels of depersonalization were related to higher incidences of job demands and higher levels of perceived lack of social support. The correlation between job demands and depersonalization was also shown to be stronger the more teachers felt they could determine the way they worked.

Personal Accomplishment

Only age $(\beta=-.14, p<.05)$, job control $(\beta=.17, p<.01)$ and the product variables job demands $x$ colleague support $(\beta=.14, p<.05)$ and self-efficacy beliefs $x$ school management support $(\beta=.16, p<.05)$ were significantly related to the personal accomplishment dimension of burnout. Personal accomplishment was higher the more teachers felt they could determine the way they worked. The teachers' scores on personal accomplishment were also higher the younger they were.

As for interactions, job control showed itself to be a moderator for the relationship between job demands on the one hand and emotional exhaustion and depersonalization on the other; colleague support was a moderator in the correlation between job demands and personal accomplishment, whereas school management support was a moderator in the correlation between self-efficacy beliefs about influencing the job and personal accomplishment.

The total variance that could be explained by the predicting variables used in step 1, 2 and 3 was 54\% for emotional exhaustion, 28\% for depersonalization and 15\% for personal accomplishment. 
Discussion

Our study, which examined burnout among PE teachers, showed that each of the components of the Karasek JDCS-model -job demands, job control, and colleague support- explained a rather significant part of the variance on at least two burnout dimensions. Especially noticeable was the variance on the variable job demands and the dimension of emotional exhaustion (Table 3 shows that $.49 \times .49=24 \%$ of the variance was explained). Furthermore, it is rather striking that job demands showed no significant correlation with personal accomplishment. The reason might be found in the fact that job demands had a direct influence on emotional exhaustion and depersonalization and might have had an indirect influence through emotional exhaustion on personal accomplishment. We found support for this supposition in Lee and Ashforth (1993).

The results also showed that the predicting variables explained a relatively high percentage of the variance on emotional exhaustion and a relatively low percentage for personal accomplishment. Obviously, personal accomplishment is a concept relatively unrelated to emotional exhaustion and depersonalization, as perceived by Walkey and Green (1992). As research suggests that personal accomplishment diminishes first when burnout develops, further research could focus on factors that are connected with this concept. According to Van Dierendonck, Schaufeli, and Buunk (2001), it is only when personal accomplishment has declined that depersonalization and emotional exhaustion develop.

Regression analysis also showed (Table 3) that school management support and selfefficacy beliefs, although significantly related to two dimensions of burnout (Table 2), did not explain any additional part of the variance on the burnout dimensions unless they interacted with either job demands, job control, or colleague support. The reason might be the location in which PE teachers give lessons, where they have less frequent social contact with colleagues and managers, which they consequently value more and consider more important. Moreover, important issues that arise in explaining the onset of burnout, e.g. classroom discipline and lack of academic achievement (Brouwers \& Tomic, 1999; Martin, 1997), are of an entirely different nature when it comes to P. E. lessons. Future studies could examine whether selfefficacy beliefs in domains different from job demands will explain part of the variance in PE teachers' burnout.

School management support and self-efficacy beliefs with respect to job demands, however, appeared to interact in the relationship with personal accomplishment. 
The importance of control as a moderator in the relationship between job demands and emotional exhaustion and between job demands and depersonalization was confirmed, whereas it was found not to be important in the relationship between job demands and personal accomplishment.

Table 3 also showed that colleague support is only an important moderator in the relationship between job demands and personal accomplishment and not in the relationship between job demands and emotional exhaustion or depersonalization.

The importance of school management support as a moderator in the relationship between self-efficacy beliefs about influencing job demands and the dimensions of burnout was affirmed for personal accomplishment only, and not for depersonalization and emotional exhaustion (in other words our hypothesis was confirmed for personal accomplishment only). Our results reveal that the P. E. teacher's age may be of some importance in explaining burnout. It may be that as they grow older, PE teachers suffer more physical complaints than other teachers. These complaints might have negative consequences for their emotional wellbeing and their ideas about personal competence. Feelings of loss, e.g. the idea of having lost youthful agility and suppleness, might be at the basis of these negative selfevaluations.

A potential limitation of our correlation design is that the causation of our findings could run in the opposite direction. Therefore, we must look at its practical implications in a more careful and nuanced way. A possible intervention aimed at prevention of burnout, could be a mindfulness-based stress reduction (MBSR) training program, supplemented with cognitive elements aimed to help teachers reflect on strategies to cope with the demands of life and work. Studies have shown that the MBSR-program can help to diminish psychosomatic symptoms among a broad spectrum of people working in a number of different occupations (Chang et al., 2004; Shapiro, Astin, Bishop, \& Cordova, 2005). In a pilot study Napoli (2004) showed that teachers who followed the MBSR-program improved in their abilities to deal with conflict and anxiety, whereby they were less prone to experience a chronic stress level, eventually resulting in burnout. Originally, the MBSR-program was an eightweek training course consisting of two and a half hour sessions that focus on learning how to relax attentively (Kabat-Zinn, 1990). Later, the program was supplemented with cognitive techniques to suit patients suffering from depression (Teasdale, Segal, \& Williams, 1995). Since job demands may have a significant impact on feelings of psychological well-being, it is important to extend the MBSR-program with cognitive elements which take issues regarding work load and the coping with this specific kind of stressors into account. Such a program could be a meaningful part of the 
curriculum for student teachers as well as a module intended to promote the professional development of PE teachers.

Our study is probably one of the first to examine burnout among a specific category of subject teachers. As stressors relating to burnout seem to differ from profession to profession, it is not too far-fetched to assume that stressors within one wide-ranging professional group such as teachers might differ from one subject to the next. Examining specific categories of subject teachers may not only reveal relationships between stressors and burnout, but also offer insight into remedies that could provide specific help in relieving the consequences of burnout. Furthermore, examining specific categories of subject teachers may make it possible to compare the working conditions of the various categories of teachers: is it indeed true that some categories of teachers are assigned more and heavier tasks than teachers in other categories? Reliable findings in this regard could prevent overburdening of teachers, which often leads to negative stress reactions and burnout. This is what burnout research should in fact be all about: helping to create healthy work environments for professionals that enable them to perform their duties in peak condition, without falling victim to avoidable diseases. Prevention is the magic word and will help save millions in social welfare payments and promote personal wellbeing for thousands.

\section{References}

Asch, D. A., Jedrziewski, M. K., \& Christakis, N. A. (1997). Response rates to mail surveys published in medical journals. Journal of Clinical Epidemiology, 50, $1129-1136$.

Babbie, E. (1995). The practice of social research. Seventh edition. Belmont, Ca., Wadsworth Publishing Company.

Bacharach, S. B. (1988). Four themes of reform: An editorial essay. Educational Administration Quarterly, 24, 484-496.

Bandura, A. (1997). Self-efficacy. The exercise of control. New York: Freeman.

Bentler, P. M. (1990). Comparative Fit Indexes in structural models. Psychological Bulletin, $107,238-246$.

Bentler, P. M., \& Bonett, D. G. (1980). Significance tests and goodness of fit in the analysis of covariance structures. Psychological Bulletin, 88, 588-606. 
Bergers, G., Marcelissen, F., \& De Wolff, C. (1986). Vragenlijst Organisatie StressDoetichem VOS-D handleiding. [Questionnaire Organizational Stress-D, manual]. Intern rapport $86 \mathrm{AO} 3$, Stressgroep publicatie No. 36. Nijmegen: Stressgroep psychologie van arbeid en organisatie.

Berkhout, P. H. G., Zijl, M., Van Praag, B. M. S. (1998). De leraar op de drempel van het millennium. Onderzoek naar de arbeidssatisfactie van leraren in het voortgezet onderwijs [The teacher on the threshold of the millennium. Research into job satisfaction among secondary school teachers]. Amsterdam: Stichting voor economisch onderzoek der Universiteit van Amsterdam.

Blase, J. (1982). A social-psychological grounded theory of teacher stress and burnout. Educational Administration Quarterly, 18, 93-113.

Borg, M. G. (1990). Occupational stress in British educational settings: A review. Educational Psychology, 10, 103-126.

Brissie, J. S., Hoover-Dempsey, K. V., \& Bassler, O. C. (1988). Individual, situational contributors to teacher burnout. Journal of Educational Research, 82, 106-112.

Brouwers, A., \& Tomic, W. (1999). Teacher burnout, perceived self-efficacy in classroom management, and student disruptive behavior in secondary education. Curriculum and Teaching, 14, 7-26.

Brownell, M. T., \& Pajares, F. (1997). Teacher efficacy and perceived success in mainstreaming students with learning and behavior problems. Annual Meeting of the American Educational Research Association. Chicago.

Burke, R. J., \& Greenglass, E. (1993). Work stress, role conflict, social support, and psychological burnout among teachers. Psychological Reports, 73, 371-380.

Burke, R. J., \& Greenglass, E. R. (1989a). It may be lonely at the top but it's less stressful: Psychological burnout in public schools. Psychological Reports, 64, 615-623.

Burke, R. J., Greenglass, E. R., \& Schwarzer, R. (1996). Predicting teacher burnout over time: Effects of work stress, social support, and self-doubts on burnout and its consequences. Anxiety, Stress, and Coping, 9, 261-275.

Burke, R. J., Shearer, J., \& Deszca, G. (1984). Burnout among men and women in police work: An examination of the Cherniss model. Journal of Health in Human Resources of Administrators, 7, 162-188. 
Centrale Financiën Instellingen (2007). Overzicht docenten lichamelijke opvoeding [A survey of physical education teachers]. Zoetermeer: Ministerie van Onderwijs, Cultuur en Wetenschappen.

Chang, V. Y., Palesh, O., Caldwell, R., Glasgow, N., Abramson, M., Luskin, F., et al. (2004). The effects of a mindfulness-based stress reduction programme on stress, mindfulness self-efficacy, and positive states of mind. Stress and Health, 20, 141-147.

De Jonge, J. D., Landeweerd, J. A., \& Van Breukelen, G. J. (1994). De Maastrichtse Autonomielijst: Achtergrond constructie en validering [The Maastricht Autonomy Questionnaire: Background, construction and validation]. Gedrag en Organisatie, 7, 2741.

De Vries, S., Beune, E., Simons, J., \& Thijsen, E. (2000). Fysieke overbelasting van docenten lichamelijke opvoeding [Physical overload of physical education teachers]. Lichamelijke Opvoeding, 88, 402-404.

Dignam, J. T., \& West, S. G. (1988). Social support in the workplace: Tests of six theoretical models. American Journal of Community Psychology, 16, 701-724.

Farber, B. A. (1991). Crisis in education: Stress and burnout in the American teacher. San Francisco: Jossey-Bass.

Fejgin, N., Talmor, R., \& Erlich, I. (2005). Inclusion and burnout in physical education. European Physical Education Review, 11, 29-50.

Fejgin, N., Ephraty, N. \& Ben-Sira, D. (1995). Work environment and burnout of physical education teachers. Journal of Teaching in Physical Education, 15, 64-78.

Friedman, I. A., \& Farber, B. A. (1992). Professional self-concept as a predictor of teacher burnout. Journal of Educational Research, 86, 28-35.

Green, K. A., \& Hutchinson, S. R. (1996). Reviewing the search on mail survey response rates: Meta-analysis. (ERIC Document Reproduction Service No. ED 402309.)

Glass, D. C., McKnight, J. D. (1996). Perceived control, depressive symptomatology, and professional burnout: A review of the evidence. Psychology and Health, 11, 23-48.

Hodge, G. M., Jupp, J. J., \& Taylor, A. J. (1994). Workstress, distress and burnout in music and mathematics teachers. British Journal of Educational Psychology, 64, 65-76. 
Jackson, S. E., Schwab, R. L., \& Schuler, R. S. (1986). Toward an understanding of the burnout phenomenon. Journal of Applied Psychology, 71, 630-640.

Jonge, J. d., Landeweerd, J. A., \& Van Breukelen, G. J. P. (1994). De Maastrichtse Autonomielijst: achtergrond, constructie en validering [Maastricht autonomy questionnaire: background, construction and validation]. Gedrag en Organisatie, 7, 2741.

Jonge, J. de, Dormann, C., Janssen, P. P. M., Dollard, M. F., Landeweerd, J. A., \& Nijhuis, F. J. N. (2001). Testing reciprocal relationships between job characteristics and psychological well-being: A cross-lagged structural equation model. Journal of Occupational and Organizational Psychology, 74, 29-46.

Kabat-Zinn, J. (1990). Full catastrophe living: Using the wisdom of your body and mind to face stress, pain, and illness. New York: Delacourt.

Kanfer, R., \& Zeiss, A. M. (1983). Depression, interpersonal standard setting, and judgements of self-efficacy. Journal of Abnormal Psychology, 92, 319-329.

Karasek, R. A., \& Theorell, T. (1990). Healthy work: Stress, productivity, and the reconstruction of working life. New York: Basic Books.

Kavanagh, D. J. (1992). Self-efficacy and depression. In Self-efficacy: Thought Control of Action, R. Schwarzer, (Ed). pp. 177-193. Washington: Hemisphere.

Koustelios, A., \& Tsigilis, N. (2005). Relationship between burnout and job satisfaction among physical education teachers: A multivariate approach. European Physical Education Review, 11, 189-203.

Kuzsman, F. J., \& Schnall, H. (1987). Managing teachers' stress: Improving discipline. The Canadian School Executive, 6, 3-10.

Lee, A. (2004). Occupational stress and burnout among Korean secondary physical education teachers: testing the job demands-control-support model. Ph.D. Dissertation. University of North Carolina at Greensboro.

Lee, R. L., \& Ashforth, B. E. (1993). A longitudinal study of burnout among supervisors and managers: Comparisons between the Leiter and Maslach (1988) and Golembiewski et al. (1986) models. Organizational Behavior and Human Decision Processes, 54, 369-398. 
Magnée, P. (2000). Stress en burnout nog steeds nummer één reden voor afkeuring. Onderwijs zet vaart achter reintegratie overspannen leerkrachten [Stress and burnout still number one reason for inability for work. Education presses for reintegration of overstressed teachers]. Schooljournaal, 4, 8-9.

Martin, M. (1997). Report to the Minister for Education on Discipline in Schools. Dublin: Ministry of Education.

Maslach, C., \& Jackson, S. E. (1986). Maslach burnout inventory manual. Journal of Occupational Behavior Palo Alto, CA: Consulting Psychologists Press.

Merseth, K. K. (1992). First aid for first-year teachers. Phi Delta Kappan, 73, 678-683.

Napoli, M. (2004). Mindfulness training for teachers: a pilot program. Complementary Health Practice Review, 9, 31-42.

Nunnally, J. C., \& Bernstein, I. H. (1994). Psychometric theory. Third Edition. New York: McGraw-Hill.

Punch, K. F., \& Tuettemann, E. (1990). Correlates of psychological distress among secondary school teachers. British Educational Research Journal, 16, 369-382.

Rakovac, M., \& Heimer, S. (2008). Work conditions: a health risk factor in physical education teachers? 5th International Scientific Conference on Kinesiology. Zagreb: Croatia. University of Zagreb.

Ross, R. R., Altmaier, E. M., \& Russel, D. W. (1989). Job stress, social support, and burnout among counseling center staff. Journal of Counseling Psychology, 36, 464-470.

Russell, D. W., Altmaier, E., \& Van Velzen, D. (1987). Job-related stress, social support, and burnout among classroom teachers. Journal of Applied Psychology, 72, 269-274.

Schaufeli, W. B., Daamen, J., \& Van Mierlo, H. (1994). Burnout among Dutch teachers: An MBI-validity study. Educational and Psychological Measurement, 54, 803-812.

Schaufeli, W. B., \& Van Horn, J. E. (1995). Maslach Burnout Inventory voor leraren (MBI-NLLe). Voorlopige handleiding. [Maslach Burnout Inventory for teachers. Preliminary guide] University of Utrecht: PAGO.

Schaufeli, W. B., \& Buunk, B. P. (2001). Toward a process model of burnout: Results from a secondary analysis. European Journal of Work \& Organizational Psychology, 10, 41-52. 
Schwab, R. L., Jackson, S. E., \& Schuler, R. S. (1984). Educator burnout: Sources and consequences, New Orleans, LA. (ERIC Document Reproduction Service No. 346 451).

Shapiro, S. L., Astin, J. A., Bishop, S. R., \& Cordova, M. (2005). Mindfulness-based stress reduction for health care professionals: results from a randomized trial. International Journal of Stress Management, 12, 164-176.

Smith, D., \& Leng, G. W. (2003). Prevalence and Sources of Burnout in Singapore Secondary School Physical Education Teachers. Journal of Teaching in Physical Education, 22, 203-218.

Smulders, P. G. W. (1995). Arbeid en gezondheid: Inleiding [Work and health: Introduction]. In Arbeid en Gezondheid [Work and Health], P. G. W. Smulders, J. M. J. Op de Weegh, (Eds.). Utrecht: Lemma.

Sonderen, E. van (1991). Het meten van sociale steun [The measurement of social support]. Groningen: University of Groningen.

Sonderen, E. v., \& Ormel, J. (1997). Het meten van aspecten van sociale steun en hun relatie met welbevinden: Een onderzoek naar de bruikbaarheid van de SSL-I en de SSL-D. [Measuring aspects of social support and their relationships with well-being: A study into the quality of the SSL-I and the SSL-D]. Gedrag \& Gezondheid, 25, 190200.

Teasdale, J. D., Segal, Z., \& Williams, J. M. G. (1995). How does cognitive therapy prevent depressive relapse and why should attentional control (mindfulness) training help? Behavioural Research Therapy, 33, 25-39.

Travers, C. J., \& Cooper, C. L. (1993). Mental health, job satisfaction and occupational stress among UK teachers. Work \& Stress, 7, 203-219.

Tschannen-Moran, M., \& Woolfolk Hoy, A. (2002). The influence of resources and support on teachers' efficacy beliefs. New Orleans, LA.

Tummers, G. E. R., Landeweerd, J. A., Janssen, P. P. M., \& Merode, G. G. van. (2006). Organizational characteristics, work characteristics, and relationships with psychologic work reactions in nursing: A longitudinal study. International Journal of Stress Management, 13, 201-227. 
Van Dierendonck, D., Schaufeli, W. B., \& Buunk, B. P. (2001). Toward a process model of burnout: Results from a secondary analysis. European Journal of Work \& Organizational Psychology, 10, 41-52.

Vrugt, A. (1995). Perceived self-efficacy: Theoretisch kader en toepassingen [Perceived self-efficacy: Theoretical framework and applications]. In Mentale belasting in het werk, M. J. Schabracq, J. A. M. Winnubst, J. Perreijn, (Eds.), pp. 219-234. Utrecht: Lemma.

Walkey, F. H., \& Green, D. E. (1992). An exhaustive examination of the replicable factor structure of the Maslach Burnout Inventory. Educational \& Psychological Measurement, $52,309-323$.

Woodruff, S. L., \& Cashman, J. F. (1993). Task, domain, and general self-efficacy: A reexamination of the self-efficacy scale. Psychological Reports, 72, 423-432.

Zabel, R., \& Zabel, M. K. (1982). Factors in burnout among teachers of exceptional children. Exceptional Child, 49, 261-263.

About the authors:

André Brouwers is currently at the Open University of the Netherlands, Department of Psychology. He has published widely in the field of occupational and organizational psychology, in particular on burnout. His current work centers on coaching and mindfulness research.

Address for correspondence: André Brouwers, Department of Psychology, The Open University, P.O. Box 2960, NL-6401 DL Heerlen, The Netherlands

E-mail: andre.brouwers@ou.nl

Welko Tomic is currently at the Open University of the Netherlands, Department of Psychology. He has published extensively on issues related to teacher behavior, transfer, and burnout. His current work focuses on creativity research, existential fulfillment, work engagement and psychosocial disorders. E-mail: welko.tomic@ou.nl

Huibrecht Boluijt is a former physical education teacher with a master degree in psychology. Currently, he is a health psychologist and owner of a psychological centre. 